KONSTRUKTIVISME, Vol. 7, No. 2, Juli 2015

p-ISSN: 1979-9438, e-ISSN: 2445-2355

FKIP Universitas Islam Balitar, Blitar

Web: konstruktivisme.unisbablitar.ejournal.web.id

\title{
PENERAPAN METODE KOOPERATIF TIPE TPS DALAM PENINGKATAN MOTIVASI DAN PARTISIPASI SISWA SERTA KUALITAS HASIL BELAJAR MATEMATIKA DI SMK NEGERI 1 BALIKPAPAN
}

\author{
Sigit Purwanto \\ SMKN 1 Balikpapan
}

\begin{abstract}
This study investigates how Think-Pair-Share techniques improve motivation and students' participation in learning mathematics. The design of this study is classroom action research implementing four phases: planning, implementing, observing, and reflection. The subject of this study is the XII grade students of Multimedia Department of SMKN 1 Balikpapan. This study implements three cycles where every cycle has two meetings. Data are collected using observation and test conducted at the end of every cycle. The study shows that learning activities in every cycle improve. The average scores in the every cycle shows that 45.8, 80,9 and 89,5 respectively in cycle I, cycle II, and cycle III.
\end{abstract}

Keywords: cooperative, think-pair-share, active student

\begin{abstract}
Abstrak
Penelitian ini mengkaji mengenai bagaimana Think-Pair-Share meningkatkan motivasi dan participasi siswa dalam pembelajaran matermatika. Penelitian menggunakan rancangan penelitian tindakan kelas dengan empat fase: perencanaan, pelaksanaan, pengamatan, dan refleksi. Subjek penelitian ialah siswa kelas XII Jurusan Multimedia SMKN 1 Balikpapan. Penelitian menerapkan dua siklus dan setiap siklus terdiri dari dua tatap muka. Data dikumpulkan menggunakan observasi dan tes pada setiap siklus. Hasil penelitian menunjukkan bahwa aktivitas belajar meningkat pada setiap siklus. Rerata nilai setiap siklus berturut-turut ialah 45.8; 80.9 dan 89.5.
\end{abstract}

Kata-kunci: kooperatif, think-phare-share, siswa aktif.

Memperoleh Pendidikan yang layak adalah hak dari setiap warga negara Indonesia. Pendidikan merupakan investasi jangka panjang yang sangat penting bagi kemajuan bangsa dan Negara , maka dari itulah mutu dan kualitasnya harus terus menerus ditingkatkan sesuai dengan perkembangan jaman. Lulusan yang diharapkan adalah yang mampu bersaing di era globalisasi, kompetitif, kreatif dan inovatif. Balitbang Depdiknas, (2003) mengartikan bahwa pendidikan berkualitas adalah 
Purwanto, Sigit. 2015. Penerapan Metode Kooperatif Tipe TPS

pendidikan yang menghasilkan lulusan yang memiliki kognitif tinggi, budi pekerti yang baik, jujur dan bertaqwa.

Untuk mewujudkan tujuan pendidikan tersebut, perlu dikembangkan berbagai model pembelajaran yang dapat meningkatkan minat belajar siswa, menyenangkan dan berorientasi pada kompetensi siswa. Sujana,(1996) menyatakan Pendidikan pada hekekatnya adalah usaha membudayakan manusia atau memanusiakan manusia.

Manusia itu sendiri adalah pribadi yang utuh dan pribadi yang kompleks sehingga sulit dipelajari secara tuntas. Oleh karena itu, masalah pendidikan tak akan pernah selesai, sebab hakekat manusia itu sendiri selalu berkembang mengikuti dinamika kehidupanya. Sehingga proses pendidikan haruslah mampu meningkatkan kemauan, motivasi untuk mengembangkan kemampuan diri dalam berkompetisi, menumbuhkan sikap kreatif inovatif dan selalu meningkatkan mutu secara berkesinambungan. Semiawan, dkk (1988) menyatakan bahwa motivasi adalah daya dalam pribadi seseorang yang mendorongnya untuk melakukan sesuatu. Ada dua jenis motivasi, yaitu motivasi yang berasal darii dalam diri anak (instrinsik) dan motivasi yang berasal dari luar (ekstrinsik). Motivasi dari dalam dapat dilakukan dengan menggairahkan perasaan ingin tahu anak, keinginan untuk mencoba, dan hasrat untuk maju dalam belajar. Motivasi dari luar dapat dilakukan dengan memberikan ganjaran, misalnya melalui pujian dan hukuman, misalnya dengan penugasan untuk memperbaiki pekerjannya.

Dalam penelitian yang melakukan pembelajaran menggunakan metode Kooperatif dengan pendekatan Think-Pair-Share (TPS) dapat meningkatkan kreatifitas, motivasi dan partisipasi siswa dalam pembelajaran matematika. Dengan hasil penelitian ini dapat memberikan kontribusi langsung pada peningkatan kualitas pembelajaran matematika sehingga tingkat penguasaan kompetensi dan mutu hasil belajar siswa dapat ditingkatkan sesuai dengan sasaran mutu sekolah. Metode pembelajaran kooperatif dengan pendekatan TPS dapat meningkatkan motivasi, partisipasi siswa dan kualitas hasil belajar siswa pada mata pelajaran matematika di SMK Negeri 1 Balikpapan.

Pembelajaran kooperatif merupakan suatu konsep dimana siswa belajar dalam kelompok-kelompok kecil yang memiliki tingkat kemampuan berbeda. Dalam menyelesaikan tugas kelompok, setiap anggota saling bekerja sama dan membantu untuk memahami suatu bahan pembelajaran. Belajar belum selesai jika salah satu teman dalam kelompok belum menguasai bahan pembelajaran (Depdiknas, 2002). Jadi, sistem pembelajaran kooperatif dapat didefinisikan sebagai sistem kerja kelompok yang terstruktur (Lie, 2004). Dalam pembelajaran kooperatif siswa tidak bisa begitu saja membonceng jerih payah rekannya, namun usaha setiap siswa akan dihargai dengan poin-poin perbaikannya.

Nurhadi (2004) menyatakan bahwa pembelajaran kooperatif adalah pendekatan pembelajaran yang berfokus pada penggunaan kelompok kecil siswa untuk bekerja sama dalam memaksimalkan kondisi belajar untuk mencapai tujuan belajar. Jadi, pembelajaran kooperatif merupakan model pembelajaran yang menggunakan kelompok kecil siswa untuk 
bekerjasama serta melatih interaksi siswa dalam rangka memaksimalkan kondisi belajar untuk mencapai tujuan belajar.

Pembelajaran kooperatif dapat merealisasikan kebutuhan siswa dalam belajar, berfikir, memecahkan masalah, dan mengintegrasikan pengetahuan dengan ketrampilan yang mereka miliki. Terdapat tujuh unsur dalam pembelajaran kooperatif (Ibrahim, dkk, 2002) yaitu:

a. Siswa dalam kelompoknya haruslah beranggapan bahwa mereka sehidup sepenanggungan bersama

b. Siswa bertanggungjawab atas segala sesuatu di dalam kelompoknya

c. Siswa haruslah membagi tugas dan tanggung jawab yang sama di antara anggota kelompok

d. Siswa harus melihat bahwa setiap anggota kelompok memiliki tujuan yang sama

e. Siswa akan di evaluasi dan diberikan penghargaan

f. Siswa membutuhkan ketrampilan untuk belajar bersama selama proses belajar

g. siswa akan diminta mempertanggungjawabkan secara individual meteri yang akan ditangani dalam kelompoknya.

Terdapat enam langkah utama atau fase dalam pembelajaran yang menggunakan metode kooperatif. Keenam fase pembelajaran kooperatif itu dirangkum pada tabel berikut:

Tabel 1. Sintaks/Langkah Pembelajaran Kooperatif

\begin{tabular}{|c|c|c|}
\hline No & Fase & Tindakan Guru \\
\hline 1 & $\begin{array}{l}\text { Fase } 1 \\
\text { Menyampaikan tujuan dan } \\
\text { memotivasi siswa }\end{array}$ & $\begin{array}{l}\text { Guru mennyampaikan semua tujuan } \\
\text { pelajaran yang ingin dipacapi pada } \\
\text { pelajaran tersebut dan memotivasi } \\
\text { siswa belajar }\end{array}$ \\
\hline 2 & $\begin{array}{l}\text { Fase } 2 \\
\text { Menyajikan informasi }\end{array}$ & $\begin{array}{l}\text { Guru menyajikan informasi kepada } \\
\text { siswa dengan jalan } \\
\text { demonstrasi/presentasi menggunakan } \\
\text { multi-media atau lewat wokrhseet/LKS } \\
\text { yang dibagikan }\end{array}$ \\
\hline 3 & $\begin{array}{l}\text { Fase } 3 \\
\text { Mengorganisasikan siswa ke } \\
\text { dalam kelompok-kelompok } \\
\text { belajar }\end{array}$ & $\begin{array}{l}\text { Guru menjelaskan kepada siswa } \\
\text { bagaimana caranya membentuk } \\
\text { kelompok belajar dan membantu } \\
\text { setiap kelompok agar melakukan } \\
\text { transisi secara efisien }\end{array}$ \\
\hline 4 & $\begin{array}{l}\text { Fase } 4 \\
\text { Meimbimbing kelompok bekerja }\end{array}$ & $\begin{array}{l}\text { Guru membimbing kelompok belajar } \\
\text { pada saat mereka mengerjakan tugas }\end{array}$ \\
\hline 5 & $\begin{array}{l}\text { Fase } 5 \\
\text { Evaluasi }\end{array}$ & $\begin{array}{l}\text { Guru mengevaluasi hasil belajar } \\
\text { tentang materi yang telah dipelajari } \\
\text { atau setiap kelompok } \\
\text { mempresentasikan hasil kerjanya }\end{array}$ \\
\hline 6 & $\begin{array}{l}\text { Fase } 6 \\
\text { Memberikan penghargaan }\end{array}$ & $\begin{array}{l}\text { Guru mencari cara untuk menghargai } \\
\text { baik upaya maupun hasil belajar } \\
\text { individu dan kelompok }\end{array}$ \\
\hline
\end{tabular}


Purwanto, Sigit. 2015. Penerapan Metode Kooperatif Tipe TPS

(Ibrahim, dkk, 2002)

Nur (2005) mengemukakan: sebuah pembelajaran koopertif yang sederhana namun berguna di sebut Think-Pair-Share yang dikembangkan oleh Frank Lyman dari Universitas Maryland. Pada saat guru mempresentasikan sebuah pelajaran di kelas, siswa duduk berpasangan di dalam tim mereka. Guru meminta kepada siswa untuk think (berfikir) sendiri jawaban pertanyaan, kemudian pair (berpasangan) dengan pasangannya berdiskusi untuk mencapai kesepakatan atas jawaban tersebut dan selanjutnya guru meminta untuk share (berbagi) jawaban dengan seluruh siswa

Keunggulan dari metode ini adalah memberikan kesempatan kepada siswa untuk bekerja sama dan juga optimalisasi partisipasi siswa lebih di utamakan. Jadi pendekatan metode TPS merupakan salah satu tipe pendekatan struktural dimana siswa terbagi dalam kelompok kecil terdiri 4-6 anggota dan siswa dituntut untuk berfikir, berdiskusi, berpasangan serta berbagi dengan seluruh kelas atas pertanyaan yang diberikan oleh guru.

Sintak untuk pembelajaran kooperatif dengan pendekatan TPS terdiri tiga tahapan, yaitu:

Tabel 2. Sintaks pembelajaran kooperatif tipe TPS

\begin{tabular}{lll}
\hline No & Tahap & Aktifitas Siswa \\
\hline 1 & Tahap 1 & $\begin{array}{l}\text { Setiap siswa diminta memikirkan } \\
\text { pertanyaan atau penyataan secara mandiri } \\
\text { untuk beberapa saat }\end{array}$ \\
\hline 2 & $\begin{array}{l}\text { Tahap 2 } \\
\text { Pairing (berpasangan) }\end{array}$ & $\begin{array}{l}\text { Siswa berpasangan dengan siswa lain } \\
\text { untuk mendiskusikan apa yang telah } \\
\text { dipikirkan pada Tahap 1 }\end{array}$ \\
\hline 3 & Tahap 3 & $\begin{array}{l}\text { Pasangan yang terbentuk pada tahap 2 } \\
\text { diminta untuk berbagi dengan sluruh siswa } \\
\text { di kelas (presentasi) tentang hasil diskusi } \\
\text { yang telah mereka bicarakan }\end{array}$ \\
\hline
\end{tabular}

Tabel 3. Tahapan Pelaksanaan TPS

Tahap -1

Thinking (berfikir) Setiap siswa diminta memikirkan pertanyaan atau pernyataan secara mandiri untuk beberapa saat.

Tahap-2 Siswa berpasangan dengan siswa lain untuk mendiskusikan apa Pairing (berpasangan) yang telah dipikirkan pada tahap - 1

Tahap -3

Pasangan yang terbentuk pada tahap - 2 di minta untuk berbagi Share (berbagi) dengan seluruh siswa 
di kelas (presentasi) tentang hasil diskusi yang telah mereka bicarakan

Dari penerapan model belajar kooperatif dengan pendekatan ThinkPair -Share ini banyak keuntungan yang diperoleh, diantaranya :

1. Meningkatnya hasil belajar yang lebih baik dibanding penggunaan model pembelajaran tradisional dan lebih efektif digunakan untuk memecahkan masalah pembelajaran karena siswa terlibat aktif.

2. Meningkatnya rasa tanggung jawab peserta didik baik secara individu maupun kelompok. Siswa trampil mengadakan hubungan sosial seperti kerja sama, komunikas, toleransi, menghargai pendapat, dan menerima kritik dari orang lain.

\section{METODE}

Penelitian ini dilaksanakan selama tiga siklus dengan pembelajaran kooperatif tipe Think-Pairs-Share. Penelitian dilaksanakan dengan metode Penelitian Tindakan Kelas (PTK), yang terdiri dari empat tahap, yaitu perencanaan, pelaksanaan tindakan, observasi dan refleksi. Penelitian ini dilakukan pada siswa Kelas 3 Multimedia SMK Negeri 1 Balikpapan selama 3 bulan. Pelaksanaan penelitian tindakan ini dilakukan pada waktu kegiatan belajar mengajar berlangsung.

\section{HASIL DAN PEMBAHASAN}

Melalui penerapan pembelajaran tipe TPS ternyata dapat meningkatkan prestasi hasil belajar dan persentase kelulusan siswa. Hal ini bisa dilihat dari nilai dasar sebelumnya, dimana hanya $10,5 \%$ siswa yang lulus dan sebanyak $89,5 \%$ yang belum lulus, sekarang menjadi kebalikannya yang lulus $89,5 \%$ dan yang belum lulus $10,5 \%$, mengalami peningkatan sebesar $79,5 \%$. Oleh karena itu pembelajaran matematika dengan model pembelajaran kooperatif tipe TPS ini dapat direkomendasikan sebagai model pembelajaran yang baik, selain pembelajaran lebih menarik, juga seluruh siswa belajar lebih aktif, kreatif dan mandiri.

\section{Siklus 1}

Data situasi kelas dalam proses kegiatan belajar mengajar

a. Ketika guru menyampaikan tujuan dan memotivasi siswa keadaan kelas kurang kondusif dan motivasi kurang maksimal, karena siswa kurang serius dalam memperhatikan guru. Beberapa siswa terlihat belum siap menerima pembelajaran dengan model ini, terbukti adanya peran siswa dalam kelompok yang belum maksimal terlebih dengan meteri yang baru. Beberapa siswa yang telah menyiapkan di rumah terlihat lebih antusias dan senang dengan metode ini, namun secara keseluruhan perlu terus ditingkatkan, terutama memotivasi dan peran siswa dalam kelompok untuk dapat mengerjakan LKS yang diberikan guru. Kendalanya, penguasaan kelas belum optimal dikarenakan faktor siswa yang belum terbiasa dengan sistem 
Purwanto, Sigit. 2015. Penerapan Metode Kooperatif Tipe TPS

pembelajaran kooperatif tipe TPS, sehingga hanya beberapa siswa terlihat sangat aktif sementara yang lain hanya terlihat diam. Usaha untuk mengatasi hal tersebut, guru lebih profesional lagi dan lebih siap lagi menghadapi kendala tersebut.

b. Saat guru memberikan LKS, siswa terlihat lebih serius dan memperhatikan,. keadaan kelas semakin kondusif, beberapa pertanyaan diberikan secara terstruktur dan jelas kepada siswa untuk kemudian diselesaikan oleh siswa bersama tim kerja. Dalam hal ini siswa diberikan pengarahan singkat/petunjuk mengerjakan LKS yang telah diberikan oleh guru

c. Saat mengorganisasi siswa ke dalam bentuk kelompok, keadaan kelas mulai terjadi sedikit gaduh. Hal ini disebabkan peralihan tempat duduk antar siswa. Setelah siswa dihadapkan untuk mengerjakan dan menelaah setiap tugas kelompok mereka mulai terlihat termotivasi dan merasakan adanya tanggung jawab yang harus dikerjakan. Kemudian mereka dituntut untuk menganalisis serta menyelesaikan masalah yang telah diberikan.

d. Saat guru membimbing kelompok untuk bekerja dan belajar, guru harus selalu siap membantu siswa sewaktu-waktu. Akan tetapi dalam hal ini guru tidak ikut campur terlalu banyak karena dapat menganggu siswa. Jadi siswa lebih ditekankan untuk mengerjakan soal sendiri sesuai inisiatifnya sendiri. Disini juga ditemukan ada beberapa siswa yang masih kurang jelas dengan petunjuk yang ada pada LKS, maka guru membantu seperlunya. Tetapi guru hanya sebagai fasilitator yang mengarahkan, sedangkan siswa yang megerjakan sesuai dengan petunjuk yang ada pada LKS.

e. Setiap kelompok diberikan kesempatan untuk mempresentasikan hasil kerjanya di depan kelas, dengan guru sebagai moderator sekaligus narasumber. Saat presentasi berlangsung tampak semua siswa antusias memperhatikan rekan-rekannya yang sedang presentasi atau menuliskan jawaban di papan tulis. Setelah selesai mempresentasikan hasil kerjanya, guru memberi waktu untuk melakukan tanya jawab atas jawaban yang belum dimengerti. Berdasarkan jawaban yang diberikan guru memberikan penghargaan kepada kelompok yang telah mempresentasikan hasil kerjanya dengan baik. Penghargaan yang diberikan berupa aplause. Kemudian melakukan tes/kuis untuk mengetahui keberhasilan belajar siswa. Penggunaan waktu juga nampak belum optimal, terutama pada saat kerja kelompok. Usaha untuk mengatasi hal tersebut, guru selalu mengajak siswa belajar dan memberikan penghargaan kepada kelompok yang sudah bekerja dengan baik. Hal-hal yang menjadi kendala pada siklus 1 ini akan diperbaiki kembali pada siklus berikutnya, yaitu siklus 2 .

Tabel 3: Distribusi nilai tes siswa

\begin{tabular}{lccl}
\hline Interval nilai & Frekuensi & Frek relatif $(\%)$ & Kategori \\
\hline $\begin{array}{c}85,1-100 \\
\text { Istimewa }\end{array}$ & 0 & 0 & Lulus \\
\hline
\end{tabular}


FKIP Universitas Islam Balitar, Blitar

Web: konstruktivisme.unisbablitar.ejournal.web.id

\begin{tabular}{lccl}
\hline $75,1-85$ & 0 & 0 & Lulus baik \\
\hline $60,0-75,0$ & 5 & 26,3 & Lulus cukup \\
\hline$<60$ & 14 & 73,7 & Belum lulus \\
\hline
\end{tabular}

Tabel 4 Keaktifan siswa

\begin{tabular}{llcc}
\hline No & Uraian & Frekuensi & $\%$ \\
\hline 1. & Aktif & 11 Orang & $57,9 \%$ \\
\hline 2. & Tidak aktif & 8 Orang & $42,1 \%$ \\
\hline & Jumlah & 19 Orang & $100 \%$ \\
\hline
\end{tabular}

Dari data nilai 19 siswa, pada siklus ini diperoleh nilai rata-rata 53,2 dengan tingkat ketuntasan belajar $26,3 \%$, sedangkan nilai rata-rata sebelumnya 45,8 dengan tingkat ketuntasan 10,5\%, sebanyak 14 siswa atau $73,7 \%$ siswa belum lulus maka dari itu untuk peningkatan kompetensi siswa guru lebih intensif melakukan pembimbingan sambil mengontrol aktivitas siswa tersebut dalam kelompok

\section{Siklus 2}

Skenario kegiatan belajar mengajar pada siklus 2 sama seperti pada siklus 1, namun dilakukan perbaikan-perbaikan sesuai dengan hasil repleksi dan kendala-kendala yang ditemukan pada siklus 1. Perbaikan dilakukan dengan penyampaian materi yang lebih efektif yakni dengan menggunakan multimedia komputer, diskusi kelompok waktunya dibatasi dan proses scaffolding dilakukan secara efisien. Guru menyiapkan bahan yang sistematis dan mudah difahami disertai dengan contoh-contoh yang relevan. Model soal dimodifikasi agar dapat dikerjakan dengan efektif namun tidak mengurangi qualitas evaluasi. Pada saat persentasi satu kelompok di wakili oleh satu siswa sebagai juru bicara sehingga penggunaan waktu lebih efisien. Rekaman data situasi belajar mengajar di kelas adalah sebagai berikut:

a. Mengawali pelajaran guru menyampaikan tujuan, memotivasi siswa mengumumkan hasil kerja dan hasil tes formatif pada siklus sebelumnya. Ini dilakukan karena pada siklus sebelumnya kehabisan waktu untuk melakukan koreksi dan perhitungan secara menyeluruh. Beberapa siswa yang telah menyiapkan di rumah terlihat lebih antusias dan puas dengan metode ini, namun secara keseluruhan perlu terus ditingkatkan, terutama memotivasi siswa untuk dapat menyelesaikan beberapa masalah yang diberikan.

b. Saat guru memberikan LKS, siswa terlihat lebih serius dan memperhatikan, keadaan kelas lebih kondusif, beberapa pertanyaan di sampaikan oleh siswa berkaitan dengan materi yang telah dibelrikan oleh guru. Siswa lebih asyik mengerjakan tugasnya masing-masing setelah diberikan pengarahan singkat/petunjuk mengerjakan LKS oleh guru.

c. Pembentukan kelompok sesuai kelompok siswa yang telah dibentuk pada siklus 1, sehingga tidak lagi dilakukan pembentukan kelompok. Mereka mulai terlihat termotivasi, terbiasa dengan 
Purwanto, Sigit. 2015. Penerapan Metode Kooperatif Tipe TPS

dalam Peningkatan Motivasi dan Partisipasi Siswa Serta Kualitas Hasil Belajar Matematika di SMK Negeri 1 Balikpapan.

Konstruktivisme, 7(2): 130-141.

metode ini dan terlihat adanya rasa tanggung jawab terhadap tugas yang harus dikerjakan.

d. Saat guru membimbing kelompok untuk bekerja dan belajar, guru hanya sebagai fasilitator dan tidak ikut campur terlalu banyak dengan tugas yang telah diberikan, karena dapat menganggu konsentrasi siswa. Siswa lebih ditekankan untuk mengerjakan soal sendiri sesuai inisiatifnya sendiri. Guru hanya sebagai fasilitator yang mengarahkan, sedangkan siswa yang megerjakan agar terbentuk kerjasama dalam kelompok, dapat menggunakan waktu secara optimal. Kerja kelompok sudah lebih baik dibandingkan dengan pada siklus 1. Siswa sudah mulai menguasai sistem pembelajaran kooperatif terutama manajemen waktu, terlihat hampir setiap kelompok dapat menyelesaikan tugas yang diberikan, namun masih ada beberapa kelompok yang penyelesaian soalnya kurang benar.

e. Setiap kelompok mempresentasikan hasil kerjanya di depan kelas, guru sebagai moderator. Semua siswa antusias memperhatikan rekan-rekannya yang sedang presentasi atau menuliskan jawaban di papan tulis. Kemudian dilanjutkan tanya jawab seperlunya tentang jawaban yang masih kurang jelas. Berdasarkan jawaban yang diberikan guru memberikan penghargaan kepada kelompok yang telah mempresentasikan hasil kerjanya dengan baik. Penghargaan yang diberikan berupa aplause. Siswa terlihat begitu antusias ditandai dengan tepuk tangan dan sorakan yang memberikan semangat kepada kelompok yang telah maju.

Tabel 5 Distribusi nilai tes

\begin{tabular}{lccl}
\hline Interval nilai & Frekuensi & Frekrelatif $(\%)$ & Kategori \\
\hline $85,1-100$ & 0 & 0 & Lulus Istimewa \\
\hline $75,1-85$ & 0 & 0 & Lulus baik \\
\hline $60,0-75,0$ & 14 & 78,9 & Lulus cukup \\
\hline$<60$ & 5 & 21,1 & Belum lulus
\end{tabular}

Tabel 6 Keaktifan siswa

\begin{tabular}{llcc}
\hline No & Uraian & Frekwensi & Persentase \\
\hline 1. & Aktif & 13 Orang & 68,42 \\
\hline 2. & Tidak aktif & 6 Orang & 32,58 \\
\hline & Jumlah & 19 Orang & 100 \\
\hline
\end{tabular}

Pada siklus 2 sudah terlihat adanya peningkatan hasil belajar siswa yang ditandai dengan meningkatnya rata-rata nilai tes siswa dari 53,2 menjadi 65 dan dari segi persentase ketuntasan belajar juga mengalami kenaikan yang cukup tinggi. Ini menunjukkan bahwa motivasi siswa telah mengalami peningkatan dan peran kelompok sudah lebih optimal dalam melibatkan seluruh anggota untuk memahami konteks yang sedang diberikan. Kategori siswa yang lulus cukup meningkat dari 5 orang menjadi 14 orang atau dari $26,3 \%$ menjadi $78.9 \%$. Sedangkan responden yang 
belum lulus menurun dari 14 orang menjadi 5 orang atau dari 78,9\% menurun menjadi $21,1 \%$. Rata-rata nilai tes siklus 2 adalah 65 dengan ketuntasan $78,9 \%$ Pada siklus ini terlihat adanya kenaikan prestasi hasil belajar yang cukup tinggi, hal ini karena adanya motivasi yang sudah mulai tumbuh dan juga peran siswa dalam kelompok yang sudah terlihat aktif.

\section{Siklus 3}

Skenario kegiatan belajar mengajar pada siklus 3 sama seperti pada siklus 1 maupun 2, namun dilakukan perbaikan-perbaikan sesuai dengan hasil repleksi dan kendala-kendala yang ditemukan pada siklus 2 . Perbaikan dilakukan dengan penyampaian sedikit penjelasan namun lebih efektif dengan menggunakan multimedia komputer, diskusi kelompok waktunya dibatasi.

Rekaman data situasi belajar mengajar di kelas adalah sebagai berikut :

a. Guru menjelaskan beberapa materi kompetensi lanjutan, pembelajaran lebih banyak menggunakan pendekatan presentasi kelas, diskusi dan tanya jawab dengan menggunakan media LCD Projektor. Pemaparan konsep disertai contoh-contoh tidak lagi mendominasi namun lebih pada kerja kelompok.

b. Siswa lebih ditekankan untuk mandiri, diberikan kesempatan untuk bekerja dengan inisiatifnya sendiri namun tetap berkisar pada LKS yang telah dibagikan. Guru lebih memerankan sebagai fasilitator bagi siswa, sedangkan siswa yang megerjakan sesuai dengan petunjuk yang ada pada LKS.

c. Pembentukan kelompok sesuai kelompok siswa yang telah dibentuk pada siklus sebelumnya, sehingga tidak lagi dilakukan pembentukan kelompok. Mereka telah termotivasi, terbiasa dengan metode ini dan terlihat adanya rasa tanggung jawab terhadap tugas yang harus dikerjakan.

d. Guru hanya sebagai fasilitator dan tidak ikut campur terlalu banyak dengan tugas yang telah diberikan karena siswa telah terbiasa. Guru hanya sebagai fasilitator yang mengarahkan, sedangkan siswa yang megerjakan agar terbentuk kerjasama dalam kelompok, dapat menggunakan waktu secara optimal. Kerja kelompok sudah dan solid. Siswa sudah mulai menguasai sistem pembelajaran kooperatif, terlihat setiap kelompok dapat menyelesaikan tugas yang diberikan.

e. Semua siswa antusias sekali ketika wakil dari kelompok mempresentasikan hasil kerjanya di depan kelas. Semua siswa memperhatikan rekan-rekannya yang sedang presentasi. Kemudian dilanjutkan tanya jawab seperlunya hal-hal yang kurang jelas di fahami.

Tabel 7 Distribusi nilai tes siswa

\begin{tabular}{lccc}
\hline Interval nilai & Frekuensi & Frek relatif $(\%)$ & Kategori \\
\hline $\begin{array}{l}85,1-100 \\
\text { Istimewa }\end{array}$ & 0 & 0 & Lulus \\
\hline $75,1-85$ & 10 & $52,63 \%$ & Lulus baik \\
\hline
\end{tabular}


Purwanto, Sigit. 2015. Penerapan Metode Kooperatif Tipe TPS

dalam Peningkatan Motivasi dan Partisipasi Siswa Serta Kualitas Hasil Belajar Matematika di SMK Negeri 1 Balikpapan. Konstruktivisme, 7(2): 130-141.

\begin{tabular}{llll}
\hline $60,0-75,0$ & 7 & $36,84 \%$ & Lulus cukup \\
\hline$<60$ & 2 & $10,52 \%$ & Belum lulus \\
\hline
\end{tabular}

Tabel 8 Keaktifan siswa pada Siklus 3

\begin{tabular}{llrr}
\hline No & Uraian & Frekuensi & Persen $(\%)$ \\
\hline 1. & Aktif & 17 Orang & $89,5 \%$ \\
\hline 2. & Tidak aktif & 2 Orang & $10,5 \%$ \\
\hline & Jumlah & 19 Orang & $100 \%$ \\
\hline
\end{tabular}

Pada siklus 3 tingkat ketuntasan belajar sudah tercapai nilai ratarata 75,7 mengalami peningkatan yang sangat signifikan dibandingkan siklus 1 dan 2. Dari segi persentase ketuntasan belajar pun juga mengalami kenaikan yang cukup tinggi yaitu mencapai $89,5 \%$. Ini disebabkan motivasi siswa telah mengalami peningkatan cukup tinggi dan peran kelompok sudah lebih optimal dalam melibatkan seluruh anggota untuk memahami kompetensi yang sedang dipelajari, hampir semua siswa sudah menunjukkan peran aktifnya baik dalam kelompok maupun bertanya dan mengajukan pendapat. Siswa yang aktif mengalami peningkatan dari 13 orang atau $68,42 \%$ pada siklus 2 menjadi 17 orang atau $89,5 \%$. Hampir semua siswa sudah termotivasi dengan baik dan respon siswa sudah meningkat tajam karena siswa sudah bisa saling menerima dan saling memberi diantara anggota kelompok yang lain.

Beberapa pembahasan dari hasil catatan pengamat, antara lain:

1. Pada siklus 1 saat guru menyampaikan tujuan dan memotivasi siswa, keadaan kelas terlihat belum kondusif, siswa terlihat kurang serius dan kurang antusias mendengar model pembelajaran yang belum pernah mereka kenal dan biasa dilakukan. Namun pada siklus 3 model pembelajaran ini mendapat hasil yang sangat baik, guru telah berhasil memotivasi siswa yang dapat dilihat saat guru memberikan pertanyaan siswa terlihat sangat aktif. Antusiasme siswa juga dapat dilihat, pada saat mengerjakan LKS dan presentasi. Disini siswa terlihat lebih aktif, karena sebagian besar dari mereka banyak yang menjawab pertanyaan berdasarkan kesepakatan yang ditentukan oleh kelompoknya.

2. Pada saat guru menyampaikan informasi yaitu presentasi kelas, siswa-siswi terlihat serius. Keadaan kelas masih tetap kondusif, guru menyampaikan informasi verbal secara jelas kepada siswa dengan media laptop dan menggunakan power point dan memberikan petunjuk-petunjuk bagaimana cara mengerjakan LKS atau panduan belajar siswa. Pada siklus 3 respon siswa terlihat meningkat pesat yang ditunjukkan semua kelompok telah bekerja sesuai dengan aturan yang ditetapkan.

3. Pembagian kelompok pada siklus 1 masih terlihat kurang adanya kerjasama antara anggota yang satu dengan yang lain. Namun pada siklus 3 dengan anggota kelompok yang tetap, pelaksanaan diskusi dalam kelompok telah berjalan dengan baik dan lebih efektif 
di bandingkan siklus-siklus sebelumnya. Hal ini ditunjukkan dari 19 siswa yang terbagi menjadi 5 kelompok ternyata 89,5\% telah aktif mengambil peran sesuai dengan kesepakatan yang ditetapkan kelompoknya.

4. Pada saat siswa bekerja dalam kelompok, siswa-siswi terlihat serius dan aktif dalam mengerjakan lembar kerja siswa pada kelompok masing-masing, walaupun ada sebagian siswa yang masih kurang aktif. Namun guru tetap membimbing dan mengawasi jalannya diskusi sambil mengisi lembar observasi siswa. Tetapi dalam membimbing kelompok bekerja dan belajar, guru tidak ikut campur terlalu banyak, karena hal ini dapat mengurangi efektifitas siswa dalam bekerja. Siswa terlihat saling bertukar pikiran untuk menyelesaikan panduan belajar yang berkemampuan tinggi mengajari yang berkemampuan rendah sehingga di antara kelompok tidak ada yang merasa belum bisa terhadap materi yang dipelajari saambil menjawab pertanyaan yang tertera dalam LKS. Dalam hal ini siswa diberi kesempatan seluas-luasnya untuk bekerja dengan inisiatif masing-masing.

5. Pada saat ini keadaan kelas agak sedikit gaduh karena masingmasing saling tunjuk untuk menjadi juru bicara kelompoknya. Pada saat mempresentasikan hasil kerja kelompok kondisi kelas kondusif kembali, walaupun masih ada beberapa siswa yang kurang memperhatikan temannya yang lagi presentasi. Ada sedikit kendala, yaitu masih adanya kelompok yang belum menyelesaikan tugas yang diberikan, namun bisa diatasi dengan cara membimbing langsung pada saat presentasi.

\section{SIMPULAN}

Berdasarkan hasil penelitian dan pembahasan sampai dengan akhir siklus 3, diperoleh kesimpulan sebagai berikut:

1. Pembelajaran kooperatif tipe TPS dapat meningkatkan aktivitas dan hasil belajar siswa dalam mata pelajaran matematika pada materi menerapkan konsep peluang. Dari 19 siswa terdapat 5 siswa memperoleh nilai > $85(\mathrm{~A}), 7$ siswa mamperoleh nilai antara 75 dan 85 (B), 5 siswa memperoleh nilai antara 60 dan 75 (C) dan 2 siswa memperoleh nilai $<60$ (D). Namun secara keseluruhan nilai rata-rata nya adalah 80,9 berada diatas SKM yang ditetapkan sekolah yaitu 60,00 .

2. Proses belajar mengajar berlangsung efektif, aktivitas belajar siswa di dalam kelas sangat baik dengan motivasi belajar tinggi. Siswa sudah mempunyai keberanian berpendapat dan mampu menemukan jawaban secara diskusi bersama teman satu kelompok.

3. Peningkatan sangat tinggi dibanding dengan nilai awal dan kompetensi siswa lebih merata, sehingga model ini perlu dipertahankan, bahkan perlu digunakan untuk matapelajaran yang lain.

4. Faktor kendala dalam pelaksanaan pembelajaran kooperatif tipe TPS adalah faktor waktu, yang terkadang siswa kekurangan waktu dalam melakukan diskusi. Sarana dan prasarana serta kelengkapan 
Purwanto, Sigit. 2015. Penerapan Metode Kooperatif Tipe TPS dalam Peningkatan Motivasi dan Partisipasi Siswa Serta Kualitas Hasil Belajar Matematika di SMK Negeri 1 Balikpapan.

Konstruktivisme, 7(2): 130-141.

perpustakaan juga merupakan kendala namun dapat di atasi dengan kreasi guru membuat bahan ajar dan sebagian besar siswa mampu membeli buku pelajaran matematika yang dibutuhkan.

\section{DAFTAR PUSTAKA}

Anita Lie,2004.Coperatif Learning. PT. Gramedia Widiasrana Indonesia:Jakarta

Chalijah Hasan, 1994. Demensi Demensi Psikologi Pendidikan. Al-lklas, Surabaya

Conny Semiawan,A.F Tangyong dkk.1988. Pendekatan Ketrampilan Proses PT. Gramedia,Anggota Ikapi, Jakarta 1985

Depdiknas,2002.Pengajaran Terintegrasi

Ibrahim, dkk. 2000. Pembelajaran kooperatif. University Press: Surabaya

Muhammad Nur, 2005. Contoh Rencana Pelajaran dan Perangkat. UNESA sity Press: Surabaya

Nana Sujana. 1996. Cara Belajar Siswa Aktif Penerbit Sinar Baru Algesindo bekerjasama dengan Lembaga Penelitian IKIP Bandung , Bandung 1996 